\title{
Peatland Expansion's Destructive Effect of Oil Palm Plantation to Traditional Economic Resources
}

\author{
Rochgiyanti ${ }^{1}$, Sudharto P. Hadi ${ }^{2}$, Yuwanto ${ }^{3}$, Teguh Yuwono ${ }^{4}$ \\ \{rochgiyanti@yahoo.com ${ }^{1}$ \} \\ Universitas Lambung Mangkurat, Indonesia ${ }^{1}$ \\ Universitas Diponegoro, Indonesia ${ }^{2,3,4}$
}

\begin{abstract}
The expansion of oil palm plantations has various consequences. This study aims to explain various traditional economic sources on peatland but have been eroded by the expansion of oil palm plantations and analyze in the livelihood's changes of communities around oil palm plantations. The study was conducted in Tabatan Baru Village, Kuripan District. This research uses a qualitative method. Data collection is done by interview, observation, and documentation. The data analysis is performed through a process of data reduction, data presentation, and verification. The results show that the peatland ecosystem store biodiversity can provide a source of life for its surrounding community. Moreover, with the expansion of oil palm plantations, the livelihoods community has tended to diminish, some have even disappeared. These conditions have forced people to switch to new economic sources. Those who are unable to switch to a new source of the economy still maintain the remaining sources of livelihood. The management of oil palm plantations needs to be done more wisely for the sustainability of the peatland ecosystem.
\end{abstract}

Keywords: Traditional Economy, Expansion of Oil Palm Plantations, Peatland.

\section{Introduction}

Indonesia is one of the world's palm oil-producing countries. Plantations spread across the regions of Papua, Sulawesi, Kalimantan, Sumatra, and the other small islands have supported the production of palm oil. Palm oil (Elaeis Guineensis Jacq) is not a native plant in Indonesia. Palm oil is a wild ancient palm tree originated from West Africa was brought to Indonesia in 1848 by Dutch East Indies officials of the Colonial Government [1]. Palm oil is becoming very popular since the products are produced in the raw materials form of palm oil are for the food industry, goods for body care, producers of renewable energy materials, etc.

Agro industry development policy with large-scale plantation development is one of the government's efforts to obtain the sources of state revenue from the non-oil and gas sectors. The opening of palm oil plantation is expected to be one of the economic locomotives for the Indonesian economy. If the expansion of the palm oil plantations is carried out properly, palm oil can generate wealth and employment for the local communities; consequently, on the contrary, the existence of palm oil plantations can lead into land alienation, livelihoods loss of the residents, social conflicts, labor exploitation, and damage to the various ecosystems [2].

The increase of palm oil global demand is followed by the plantation expansion in various countries. In Indonesia, the area development of palm oil plantations tends to increase from time to time. In 1980, the total area of Indonesian palm oil was 294.56 thousand 
hectares, moreover, in 2015 it had already reached 11.30 million hectares and it was predicted to be 11.67 million hectares in 2016, with an average growth of $10.99 \%$ per year [3]. Furthermore, from the following data based on the concession status, palm oil plantations are divided into community plantations (PR) which control $37.45 \%$, state-owned plantations (PBN) control $11.67 \%$, and private large plantations (PBS) control 50, 77\% of the Indonesian palm oil total area. The expansion of palm oil plantations from 2013-2017 can be seen in the following table.

Table 1. The area of Palm oil Plantations According to the Cultivation Status (Ha) 2013-2017

\begin{tabular}{cccccc}
\hline No. & Year & $\begin{array}{c}\text { PR/ } \\
\text { Small-holders }\end{array}$ & $\begin{array}{c}\text { PBN/ } \\
\text { Govern-ment }\end{array}$ & $\begin{array}{c}\text { PBS/ } \\
\text { Private }\end{array}$ & Number \\
\hline 1 & 2013 & 4.356 .087 & 727.767 & 5.381 .166 & 10.465 .020 \\
2 & 2014 & 4.422 .365 & 729.022 & 5.603 .414 & 10.754 .801 \\
3 & 2015 & 4.535 .400 & 743.894 & 5.980 .982 & 11.260 .277 \\
4 & $2016^{*}$ & 4.656 .648 & 747.948 & 6.509 .903 & 11.914 .499 \\
5 & $2017^{* *}$ & 4.756 .272 & 752.585 & 6.798 .820 & 12.307 .677 \\
\hline
\end{tabular}

Source: Directorate General of Plantations [4], adjusted.

Note: ${ }^{*}$ Temporarily, ${ }^{* *}$ Estimated.

The expansion of palm oil plantations has also reached the area of South Kalimantan Province, where are 80,732 $\mathrm{Ha}(\mathrm{PR}), 16,969 \mathrm{Ha}(\mathrm{PBN})$, and 323,367 Ha (PBS) [4]. The extension of palm oil plantations spread across several districts included Barito Kuala Regency. Especially in Barito Kuala Regency, palm oil production and area can be seen in the following table.

Table 2. The Palm Oil Production and Area in Barito Kuala Regency 2015

\begin{tabular}{|c|c|c|c|c|c|c|c|c|c|}
\hline \multirow[t]{2}{*}{ No. } & \multirow[t]{2}{*}{$\begin{array}{l}\text { Cultivati } \\
\text { on Status }\end{array}$} & \multicolumn{3}{|c|}{ Width Area (Ha) } & \multirow[t]{2}{*}{ Numbers } & \multicolumn{2}{|c|}{ Productivity } & \multirow[t]{2}{*}{ Farmers } & \multirow[t]{2}{*}{ Labours } \\
\hline & & TBM & $\mathrm{TM}$ & TTM & & Production & Productivity & & \\
\hline 1 & PR & 2.225 & 168 & - & 2.393 & 641 & 3.815 & 1.052 & - \\
\hline 2 & PBS & 14.931 & 7.693 & - & 22.624 & 7.123 & 926 & - & 11.312 \\
\hline
\end{tabular}

Source: Directorate General of Plantations [4], has been processed.

In Barito Kuala Regency, the existence of palm oil plantations spread in almost all districts. In Kuripan District area, palm oil plantations are opened on the peatland, where ecosystems are very rich in biodiversity. The palm oil plantations began to enter in 2010 . The presence of palm oil plantations, on the one hand, offers the availability of jobs, both as workers on plantations and as plasma farmers; consequently, on the other hand, its presence has eroded the sources of the traditional economy sourced from the peatland ecosystem. Therefore, this study aims to explain various sources of the developed traditional economy in the peatland ecosystem, which consequently have been eroded by the expansion of palm oil plantations; and analyze the changes in the livelihoods of communities around the palm oil plantations. 


\section{Methodology}

The study was conducted in Tabatan Baru Village, Kuripan District, Barito Kuala Regency, South of Kalimantan Province. This village was chosen since there is one type of traditional economic resource only founded in the village, which is raising the buffalo cattle. However, all villages in Kuripan District were affected by the expansion of palm oil plantations. The study was conducted using qualitative methods. The type of data used is primary and secondary data. The data collection is done by interview, observation, and documentation. The data analysis is performed interactively through a process of data reduction, presentation, and verification.

\section{Results and Discussion}

Tabatan Baru village has an area of $70.50 \mathrm{~km} 2$ or $20.52 \%$ reaches $343.50 \mathrm{~km} 2$ of the total area of Kuripan District which the population is 973 people, consisting of 504 men and 469 women, with the population density of 13.80 people/ $\mathrm{km} 2$ [5]. The geographical conditions in the peatlands' form of help determine the types of work carried out by the residents. Based on the Regional Statistics of Kuripan District [6], the population majority of making a living as forest the product collectors, fishermen, and rice farmers. Housewives make woven mats. Some residents work as traders, river transportation services, and other businesses.

At the beginning of the palm oil plantations in operation, the citizens' economic resources began to erode. In the land clearing phase, beje (a kind of pond to naturally nurture fish) is also displaced. The livelihoods source of the population from the fisheries can be seen from 2011 data where there are still 100 beje, and increased up to 112 in 2012 [6], [7]. However, since 2014 the data cannot be found anymore, both in the source of Kuripan District and Barito Kuala Regency in numbers. The loss of this data is possible since the number of beje is so much reduced which is no longer as an important source of livelihood for the population. According to an informant, the loss of beje as a source of community livelihood occurred when the palm oil plantations began to operate on the open land.

The presence of palm oil plantations does employ the residents. At the beginning of the planting period, the plantation recruited many residents as day laborers on the plantation. Anyone can work on the plantation; no special requirements and skills are needed. According to the residents, they can get wages between 75 and 83 thousand rupiahs per day, depending on the number of completed jobs. Within a month, they can earn an average income of 1.5 million rupiahs, with a maximum working day of 25 days per month. They can work on plantations for around eight months. After the plants grow big and only require routine maintenance, the need for labor is greatly reduced. Therefore, a lot of labors are no longer needed. As a result, many residents lost their jobs on plantations.

For the residents, the opportunity of a return to work on plantations is when palm oil starts to produce, which many laborers are needed to harvest the palm oil bunches. This is related to the palm oil fruit character, which is 48 hours after harvest must be processed quickly therefore the oil levels do not decline [8]. During this waiting period, many residents have difficulty meeting their daily needs. When going back to work looking for fish, the fishproducing source has been much reduced, moreover the obtained-income is less. When going to look for rattan and galam, the rattan and galam forests have turned into palm oil plantations. 
In addition to the nucleus estate, some smallholdings began to be opened gradually in 2014, consequently in the research village up to 2018; the land acquisition process is still ongoing. Former landowners can become plasma farmers or those who volunteer as become plasma farmers. When becoming a plasma farmer, they plant mono cultivation. Therefore, the economic source is only from the result of oil palm. Even though to reach the harvest time, they have to wait up to five years. During the waiting period of the harvest, there is vulnerability, since there is no more diversification of the economic resources. If there is a price fluctuation at the time of harvest, they will be disadvantaged which causing the vulnerability.

According to Scoones (2015), vulnerability can occur when a well-established livelihood system experiences sudden are shocking moreover prolonged periods [9]. The residents who follow this plasma have undergone a transformation of economic orientation from the subsistence to the market economy. In a subsistence economy, the safety-first principle is emphasized, where farmers will try to avoid failures that can destroy their lives, rather than trying to obtain large profits by taking the risks [10]. This transformation has made the value of what is produced increasingly determined by the impersonal market fluctuations. In Scott's view [10]. Such a transformation has radically damaged the social and moral economic insurance patterns from a pre-existing ethic of subsistence.

The presence of palm oil plantations also encourages the growth of grocery and food stalls. From the observations, in this village, there are 25 stalls. According to information, many residents open a food stall when people are busy working on the plantations. The shop is open almost every day. However, when many residents no longer work on plantations, many stalls open only once a week in the village market every day. Another economic source that can still be expected is weaving the purun (Fimbristylis umbellar) mat, the raw material comes from purun orchards. Purun is a type of grass plant that lives near water or swamps. From the following data, the area of purun gardens reached 115 hectares (2015), increased to 320 hectares (2016), and decreased to 117 hectares (2017) [5][11][12]. The residents still maintain the weaving of purun mats, and this is the last hope when there are no other jobs.

In addition, buffalo farming also experienced a reduction in grazing land area as a source of forage for the animal feed. The land area was recorded at 13,351 Ha (2013), reduced to

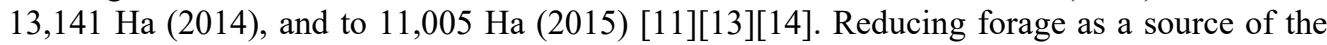
animal feed can threaten the survival of buffalo. This means threatening the economic resources for farmers, which makes buffaloes the main source of livelihood.

When many traditional economic resources were eroded by the presence of palm oil plantations, turned out these conditions encouraged the residents to turn to new sources of livelihood, namely building swallow houses. This business is only able to be run by the rich people in the village since to build a house for swallow's nests requires a cost of between 100 million - 200 million rupiahs. To be able to harvest the swiftlet nests, the owner must wait for one year. If they have harvested, they will have no difficulty in selling swallow's nests since there are already buyers who are ready to collect the harvest, regardless of the amount. According to the informant, the price of swallow's nests is very promising, it can reach 20 million rupiahs per $\mathrm{kg}$ for the super quality.

Based on the observations, in 2014 there was only one swallow house in this village, the number jumped into 49 units (2017), and increased up to 80 (2018). Although the increment number of bird's nest houses is not followed by the amount of labor's absorption since the maintenance of swallow houses and harvesting of swallow nests can be done by the owner himself. This condition will certainly lead to gaps between villagers; in turn, it will lead to vulnerability, which is vulnerable to vertical and horizontal conflicts between the residents. 
However, what residents do by developing houses for swallow nests is a rational action. The concept of rationality, used by Weber, is the key to an objective analysis of subjective meanings and also a comparison basis for different types of social action [15]. They acted rationally since the sources of the traditional economy had been difficult to develop, thus changing the orientation of the economy from a subsistence economy to a market-oriented economy. With the basic concept of rationality, Weber has made a classification of social action types, which is distinguished between rational and non-rational actions, where rational actions are related to conscious consideration and choices moreover the actions are expressed [15].

Citizens' actions are rational actions based on instrumental rationality since they are done based on conscious consideration and choice, which relates to the action purpose and the tools used to achieve it. Individuals do have a variety of objectives, and they will make a choice based on certain criteria. Based on the determined choices, they will then determine a tool that might be used to achieve the goal. In an impersonal market system, economic activity may be the basic form of this instrumental rationality. Aside from being a social action based on instrumental rationality, the emergence of new economic resources also shows resilience.

According to Berkes [9], resilience is the ability of individuals or households to withstand harmful pressures by playing a combination of capital and livelihood strategies. There are three indicators of resilience, as follows (1) buffer capacity, namely assets owned by actors, (2) self-organization, namely institutions, cooperation and networks, supporting social structures, and trust among actors whom working together; and (3) capacity of learning, namely the ability to carry out continuous learning in everyday social formation, learning from occurred threats before, then transfer knowledge to others [9].

The expansion of palm oil plantations has reached the rich biodiversity peatlands, which is a source of the traditional economy for the surrounding community. The expansion of palm oil plantations has eroded traditional economic resources. The changes in economic resources can be seen in the following table.

Table 3. The Changes of Economic Resources in Tabatan Baru Village

\begin{tabular}{|c|l|c|c|c|}
\hline \multirow{2}{*}{ No } & \multicolumn{1}{|c|}{ Type of Work } & Before Oil Palm & \multicolumn{2}{|c|}{ After Oil Palm Expansion } \\
\cline { 4 - 5 } & & Expansion & $2010-2014$ & $2015-2018$ \\
\hline 1 & Growing rice and vegetables & $\sqrt{ }$ & --- & --- \\
\hline 2 & Catch fish in rivers and swamps & $\sqrt{ }$ & $\sqrt{*}$ & $\sqrt{*}$ \\
\hline 3 & Keep fish in beje & $\sqrt{ }$ & $\sqrt{*}$ & --- \\
\hline 4 & Looking for galam & $\sqrt{ }$ & --- & --- \\
\hline 5 & Looking for wood & $\sqrt{ }$ & --- & --- \\
\hline 6 & Looking for rattan & $\sqrt{ }$ & --- & --- \\
\hline 7 & Looking for honey and catching birds & $\sqrt{ }$ & $\sqrt{*}$ & --- \\
\hline 8 & Looking for purun & $\sqrt{ }$ & $\sqrt{ }$ & $\sqrt{*}$ \\
\hline 9 & Weaving purun & $\sqrt{ }$ & $\sqrt{ }$ & $\sqrt{ }$ \\
\hline 10 & Raising buffalo swamps & $\sqrt{ }$ & $\sqrt{ }$ & $\sqrt{* *}$ \\
\hline 11 & Open a stall & $\sqrt{ }$ & $\sqrt{*}$ & $\sqrt{*}$ \\
\hline 12 & Plantation laborer & --- & $\sqrt{ }$ & --- \\
\hline 13 & Plantation employees & --- & $\sqrt{*}$ & $\sqrt{*}$ \\
\hline 14 & Swallow breeding & --- & --- & $\sqrt{ }$ \\
\hline
\end{tabular}

Source: Research result, 2018.

Note: * decreasing, ** threatened to disappear 
However, the expansion of palm oil plantations has also led to the emergence of new economic resources, although they have not opened many jobs. Such a situation can lead to vulnerability, both economic and conflict vulnerabilities. The flow of thought framework can be seen in the following scheme.

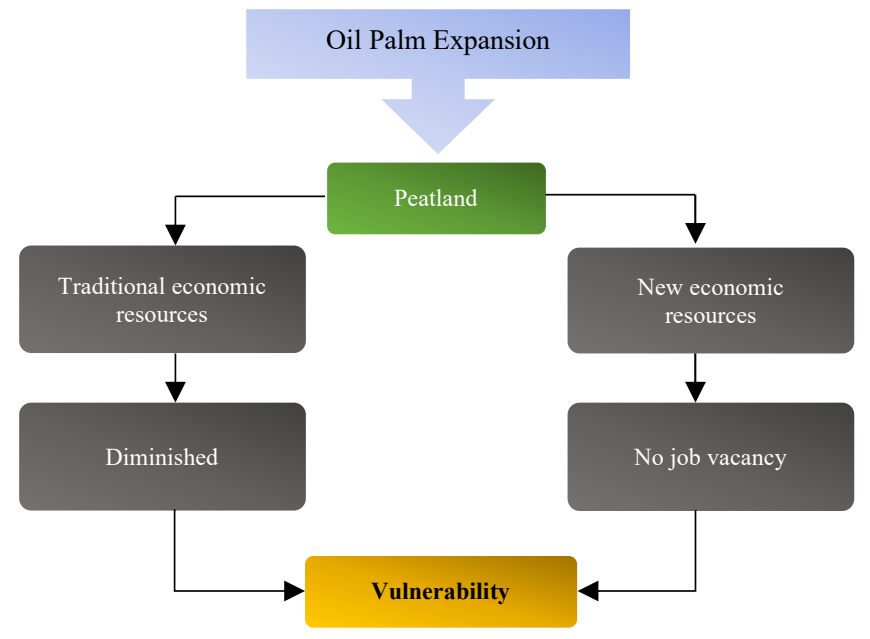

Fig. 1. Framework for Thinking

\section{Conclusion}

a) The expansion of palm oil plantations has eroded the economic resources of residents who originally depended their lives on the rich in biodiversity peatland ecosystems. The erosion of economic resources can lead to the economic vulnerability of citizens.

b) Changes in land use, from peatlands to palm oil plantations, have led to monoculture and people's dependence on palm oil commodities. If there is a fluctuation in palm oil prices, it can cause economic vulnerability.

c) At the beginning of the palm oil plantations opening is able to open jobs and move the citizens' economy, although it does not take place all the time since the availability of further employment still has to wait for the harvest time.

d) The existence of a pause in palm oil plantations employment has encouraged residents who have large capital to develop new economic resources. Although this new marketoriented business does not absorb much of the workforce, it makes it vulnerable to create gaps and conflicts.

It can be suggested that the palm oil plantations management needs to be done more wisely for the peatland ecosystem sustainability. In addition, the community traditions oriented to subsistence ethics rooted in economic habits and social exchanges in the society needed to be preserved to reduce the vulnerability and inequality among the citizens.

\subsection{Acknowledgment}

This research was achieved with the support of the research team. I would like to thank the promoter dan co-promoters for their help in reviewing this article. 


\section{References}

[1] J. G. Saragih, "Cap Buruk Perkebunan Sawit: Berawal dan Berakhir di Penataan Ruang,” J. Ilmu Sos. Transform., vol. 26, 2011.

[2] M. . et al Colchester, "Tanah Yang Dijanjikan, Minyak Sawit dan Pembebasan Tanah di Indonesia: Implikasi terhadap Masyarakat Lokal dan Masyarakat Adat,” For. Peoples Program. Sawit Watch. HuMa, dan World Agrofor. Cent., vol. 12, 2006.

[3] Pusat Data dan Sistem Informasi Pertanian, "Outlook Kelapa Sawit: Komoditas Pertanian Subsektor Perkebunan," Sekr. Jenderal, Kementeri. Pertan., 2016.

[4] Direktorat Jenderal Perkebunan, "Statistik Perkebunan Indonesia 2015-2017: Kelapa Sawit," Sekr. Direktorat Jenderal Perkebunan, Direktorat Jenderal Perkebunan, Kementeri. Pertan., 2016.

[5] Badan Pusat Statistik (BPS), Kabupaten Barito Kuala Dalam Angka 2018. Barito Kuala: BPS, 2018.

[6] Badan Pusat Statistik (BPS), Statistik Daerah Kecamatan Kuripan 2013. Barito Kuala: BPS, 2013.

[7] Badan Pusat Statistik (BPS), Kecamatan Kuripan Dalam Angka 2012. Barito Kuala: BPS, 2012.

[8] M. Chamim and M. Chamim, Raja limbung: seabad perjalanan sawit di Indonesia. Sawit Watch bersama Tempo Institute, 2012.

[9] E. B. Yulian, A. H. Dharmawan, E. Soetarto, and P. Pacheco, "Dilema Nafkah Rumahtangga Perdesaan Sekitar Perkebunan Kelapa Sawit di Kalimantan Timur," Jurnal].[Internet]. J. Sosiol. Perdesaan, vol. 5, no. 3, pp. 242-249, 2017.

[10] J. C. Scott and H. Basari, Moral ekonomi petani: Pergolakan dan subsistensi di Asia Tenggara. Lembaga Penelitian, Pendidikan dan Penerangan Ekonomi dan Sosial, 1981.

[11] Badan Pusat Statistik (BPS), Kabupaten Barito Kuala Dalam Angka 2016. Barito Kuala: BPS, 2016.

[12] Badan Pusat Statistik (BPS), Kabupaten Barito Kuala Dalam Angka 2017. Barito Kuala: BPS, 2017.

[13] Badan Pusat Statistik (BPS), Kabupaten Barito Kuala Dalam Angka 2014. Barito Kuala, 2014.

[14] Badan Pusat Statistik (BPS), Kabupaten Barito Kuala Dalam Angka 2015. Barito Kuala: BPS, 2015.

[15] D. P. Johnson and R. M. Z. Lawang, Teori sosiologi klasik dan modern. Gramedia Pustaka Utama, 1994. 